\title{
Badania naprężeń własnych w powłokach natryskiwanych metodą HVOF
}

\section{Residual stress investigations in coatings deposited by HVOF thermal spraying}

\section{Streszczenie}

W pracy przedstawiono wyniki badań naprężeń własnych w powłokach metalicznych $(\mathrm{Cu}, \mathrm{Ni}, \mathrm{Ti})$ natryskiwanych metodą HVOF na podłoża ceramiki korundowej $\mathrm{Al}_{2} \mathrm{O}_{3}$. Naprężenia w powłokach badano przez pomiar krzywizny wygięcia powłoki z podłożem oraz z wykorzystaniem zmodyfikowanego równania Stoneya opracowanego przez Clyne'a. Zbudowano model MES analizowanych układów powłoka-podłoże, który następnie poddano obciążeniu w taki sposób, aby doprowadzić badany układ do wygięcia odpowiadającego rzeczywistym zmierzonym ugięciom badanych próbek. W ten sposób uzyskano obraz stanu naprężeń własnych na przekroju badanych złączy wywołany rzeczywistym wygięciem próbek. Przedstawiono porównanie wyników wyznaczonych naprężeń w układzie powłoka-podłoże wg równań Clyne’a oraz z modelu MES.
Abstract

This paper presents the results of residual stresses estimation in the metal coatings $(\mathrm{Cu}, \mathrm{Ni}, \mathrm{Ti})$ thermally sprayed on the $\mathrm{Al}_{2} \mathrm{O}_{3}$ substrate by the HVOF method. The stresses in the coatings were tested by measuring the bending curvature of the coating and substrate samples and using a modified Stoney's formula developed by Clyne'a. The FEM model was built to analyze the coatingsubstrate systems subjected to a load, in such a way as to bring the system to obtain model deflection corresponding to the actual value measured in the real samples. This way the state of the residual stress in the joints caused by the actual curvature of the samples was obtained. A comparison of the stress results calculated by the Clyne's equations in the coating-substrate system and obtained by the FEM model was shown.

\section{Wstęp}

Jednym z ważniejszych zagadnień badawczych związanych z wytwarzaniem powłok metodami natrysku cieplnego jest występowanie w układzie powłokapodłoże naprężeń własnych [1]. Niekorzystny rozkład naprężeń własnych zarówno w powłoce, jak i na granicy powłoki i podłoża może mieć decydujący wpływ na trwałość eksploatacyjną nanoszonych materiałów. Ocena stanu naprężeń w natryskiwanych powłokach prowadzona jest metodami analitycznymi, eksperymentalnymi oraz z wykorzystaniem analiz numerycznych

Dr hab. inż. Dariusz Golański, prof. PW, dr hab. inż. Tomasz Chmielewski, mgr inż. Grzegorz Gontarz, dr inż. Jolanta Zimmerman - Politechnika Warszawska, prof. dr hab. inż. Władysław Włosiński - Instytut Maszyn Przepływowych PAN, Warszawa.

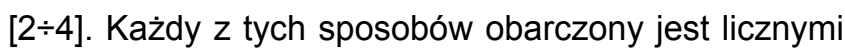
uproszczeniami, założeniami czy też błędami pomiarów, dlatego trudno jest ustalić, która z metod umożliwia dokładne określenie wielkości i rozkładu naprężeń. Najczęściej wykorzystuje się kilka metod.

W pracy przeprowadzono obliczenia naprężeń w powłokach metalicznych nanoszonych na podłoże ceramiczne z wykorzystaniem modelu analitycznego opisanego przez Clyne'a [5], który opiera się na wygięciu układu dwóch połączonych płyt. Wyznaczone wg tego modelu rozkłady naprężeń na przekroju badanych powłok uzupełnione zostały o wyniki obliczeń numerycznych (MES) dla analizowanych próbek, z których otrzymano rozkłady naprężeń powstających w czasie chłodzenia powłoki utworzonej na podłożu. Odejmując od siebie oba otrzymane rozkłady naprężeń, uzyskano informację o naprężeniu wynikającym z procesu tworzenia się powłoki na podłożu. 


\section{Model płyty - równanie Stoney’a}

Układ powłoka-podłoże możemy rozpatrywać jako połączenie dwóch płyt (rys. 1a). W wyniku różnego skurczu poprzecznego obu materiałów, powstającego w procesie ich chłodzenia, powstaje pewne niedopasowanie płyt $\Delta \varepsilon$ (rys. 1b), przy czym układ sił poprzecznych musi być w równowadze dla całego układu (rys. 1c). Efektem końcowym jest zatem wygięcie płyt związane z powstającymi momentami gnącymi M (rys.1d) i opisane krzywizną wygięcia $\mathrm{k}$.

Gdy powłoka jest dużo cieńsza od podłoża, naprężenia w podłożu stają się pomijalne, a naprężenie w powłoce nie będzie się znacząco zmieniać na grubości ze względu na powstające wygięcie płyt. Zagadnienie takie, opisane równaniem Stoneya [6] wiążącym krzywiznę wygięcia układu powłoka-podłoże $z$ naprężeniem w powłoce przedstawia zależność:

$$
\sigma_{c}=\frac{1}{6} \frac{E_{s}}{\left(1-v_{s}\right)} \frac{h_{s}^{2}}{\mathrm{~h}_{\mathrm{c}}}\left(\frac{1}{\mathrm{r}_{2}}-\frac{1}{\mathrm{r}_{1}}\right)
$$

Jeśli grubość powłoki nie jest dużo mniejsza od grubości podłoża, należy zmodyfikować równanie (1). Ponadto nie można pominąć naprężeń w podłożu, które mogą przybierać istotne wartości.

Spośród wielu różnych modyfikacji równania Stoneya najszerzej przyjął się model Tsui-Clyne'a [7], którzy opisali w sposób analityczny układ dwóch płyt o znanym niedopasowaniu $\Delta \varepsilon$, uzyskując rozwiązanie umożliwiające wyznaczenie naprężeń w powłoce i podłożu:

- naprężenie na powierzchni górnej powłoki:

$$
\sigma_{\left.c\right|_{y=h_{c}}}=-\Delta \varepsilon\left(\frac{E_{c} h_{s} E_{s}{ }^{\prime}}{h_{c} E_{c}{ }^{\prime}+h_{s} E_{s}{ }^{\prime}}\right)+E_{c}{ }^{\prime} \mathbf{k}\left(h_{c}-\delta\right)
$$

- naprężenie na powierzchni dolnej powłoki:

$$
\sigma_{\left.c\right|_{y=0}=-\Delta \varepsilon}\left(\frac{E_{c}{ }^{\prime} h_{s} E_{s}{ }^{\prime}}{h_{c} E_{c}{ }^{\prime}+h_{s} E_{s}{ }^{\prime}}\right)-E_{c}{ }^{\prime} \mathbf{K} \delta
$$

- naprężenie na powierzchni górnej podłoża:

$$
\left.\sigma_{s \mid y=0}=\Delta \varepsilon\left(\frac{E_{c}{ }^{\prime} h_{s} E_{s}{ }^{\prime}}{h_{c} E_{c}{ }^{\prime}+h_{s} E_{s}}\right)\right)-E_{s}{ }^{\prime} \mathbf{K} \delta
$$

- naprężenie na powierzchni dolnej podłoża:

$$
\sigma_{\left.s\right|_{y=-h_{s}}}=\Delta \varepsilon\left(\frac{E_{c}{ }^{\prime} h_{s} E_{s}{ }^{\prime}}{h_{c} E_{c}{ }^{\prime}+h_{s} E_{s}{ }^{\prime}}\right)-E_{s}{ }^{\prime} \mathbf{K}\left(h_{s}+\delta\right)
$$

gdzie: $\sigma_{c, s}$-naprężenie w powłoce (c) i podłożu (s), $\Delta \varepsilon=\left(\alpha_{s}-\alpha_{c}\right) \Delta \mathrm{T}$, $\alpha_{c s}-$ współczynnik rozszerzalności cieplnej powłoki i podłoża, $\Delta T$ - różnica temperatury generująca odkształcenie, $E_{c}^{\prime}=E_{c} /\left(1-v_{c}\right), E_{s}^{\prime}=E_{s} /\left(1-v_{s}\right), h_{c s}-$ grubość powłoki i podłoża, $E_{c, s}$ - moduł Younga powłoki i podłoża, $\mathbf{K}$ - krzywizna wygięcia $(1 / r), \delta$ - położenie osi obojętnej układu płyt.

Mierząc ugięcie próbek po naniesieniu powłoki można obliczyć promień oraz krzywiznę wygięcia, na podstawie których możliwe jest rozwiązanie równań (2) $\div(5)$ i wyznaczenie naprężeń w powłoce i podłożu. a)

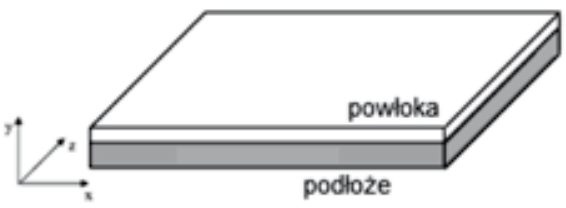

b)

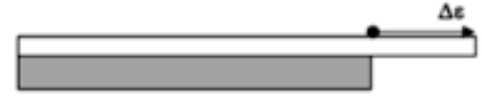

c)

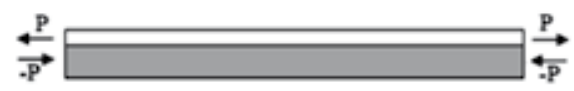

d)

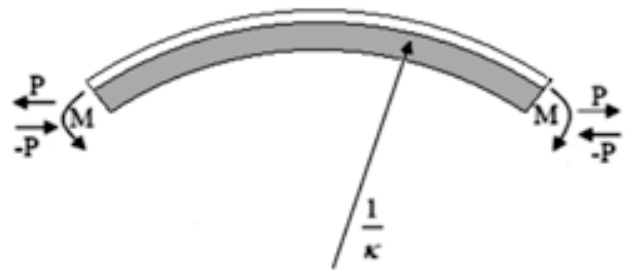

Rys. 1. Schemat powstawania wygięcia w układzie dwóch płyt opisujących powłokę i podłoże

Fig. 1. The scheme of deflection of two plates representing coating and substrate

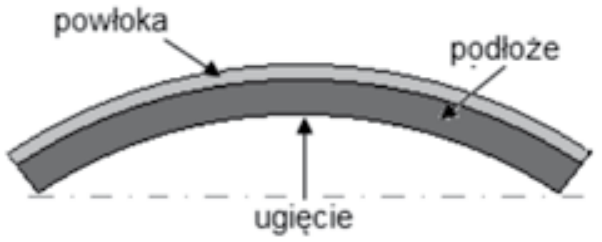

Rys. 2. Ugięcie podłoża z powłoką po natryskiwaniu

Fig. 2. The Scheme of coating/substrate deflection after thermal spraying

\section{Pomiary wygięcia próbek po natryskiwaniu}

Przeprowadzono próby nanoszenia powłok miedzianych, niklowych oraz tytanowych na podłoże ceramiki $\mathrm{Al}_{2} \mathrm{O}_{3}$ metodą natryskiwania płomieniowego naddźwiękowego (HVOF). Zastosowano system HV-50 firmy Flame Spray Technologies z palnikiem HVOF JP5000. Materiały nanoszono w postaci proszku o średnicy $40 \div 50 \mu \mathrm{m}$, a podłożem ceramicznym były płytki prostokątne o wymiarach $20 \times 30 \times 0,593 \mathrm{~mm}$. Na rysunku 3 przedstawiono zdjęcia fragmentów powierzchni otrzymanych powłok. Powierzchnia podłoża została równomiernie pokryta nanoszonymi materiałami, a uzyskane powłoki dobrze przylegają do podłoża. Efektem natrysku materiału metalicznego na podłoże ceramiczne jest wygięcie próbki spowodowane zróżnicowaniem właściwości cieplno-fizycznych dwóch różnych materiałów.

Ugięcie próbek mierzono za pomocą przyrządu z cyfrowym czujnikiem zegarowym. Płytki przed procesem były zerowane $w$ przyrządzie, a potem ponownie $w$ nim umieszczone w celu określenia wygięcia powstałego 
Tablica I. Zmierzone ugięcia próbek oraz grubości nałożonych powłok

Table I. Measured deflections and thicknesses of deposited coatings by HVOF method

\begin{tabular}{|c|c|c|c|c|c|}
\hline \multicolumn{7}{|c|}{ Ugięcie próbki, $\mathrm{mm}$} & $\begin{array}{c}\text { Średnie ugięcie } \\
\mathrm{mm}\end{array}$ & $\begin{array}{c}\text { Średnia grubość powłoki } \\
\mathrm{mm}\end{array}$ \\
\hline 1 & 2 & 3 & 4 & powłoka Cu \\
\hline 0,064 & 0,071 & 0,069 & 0,038 & 0,061 & 0,105 \\
\hline 0,088 & 0,063 & 0,052 & 0,053 & 0,064 & 0,119 \\
\hline \multicolumn{7}{|c|}{ powłoka Ti } \\
\hline 0,066 & 0,084 & 0,064 & 0,063 & 0,069 & 0,133 \\
\hline
\end{tabular}
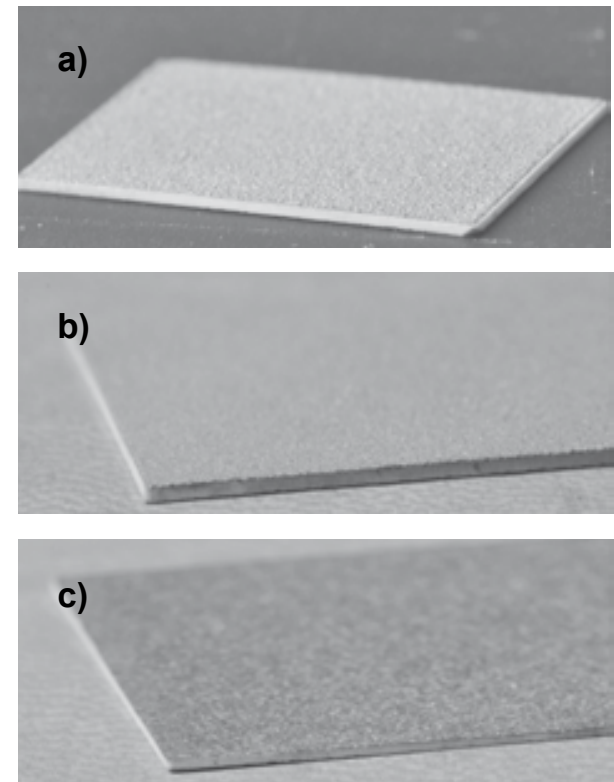

Rys. 3. Zdjęcia próbek ceramicznych z naniesionymi powłokami metalowymi: a) $\mathrm{Cu}$, b) $\mathrm{Ni}, \mathrm{c}$ ) $\mathrm{Ti}$

Fig. 3. The pictures of ceramic samples coated with: a) copper, b) nickel, c) titanium

układu powłoka-podłoże. W tablicy I przedstawiono zmierzone wartości ugięcia próbek z natryskiwanymi powłokami oraz zmierzonymi grubościami powstałych powłok. Grubości średnie badanych powłok metalowych (wyznaczone z czterech próbek) wyniosły od 0,1 do $0,133 \mathrm{~mm}$.

$\mathrm{Na}$ podstawie zmierzonego ugięcia próbek $\mathrm{h}$ oraz rozstawu podpór pomiarowych (a = $27 \mathrm{~mm}$ ), wykorzystując zależności geometryczne (rys. 4), obliczono promień krzywizny $r$ oraz krzywiznę próbek k z powłokami.

\section{Model MES powłoka-podłoże}

W celu porównania wyników naprężeń w powłoce i podłożu, otrzymanych z pomiarów krzywizny wygięcia próbek oraz równań opracowanych przez Stoneya i Clyne'a, zbudowano model elementów skończonych układu powłoka-podłoże odpowiadający geometrii analizowanych próbek. Model ten odzwierciedlał geometrię
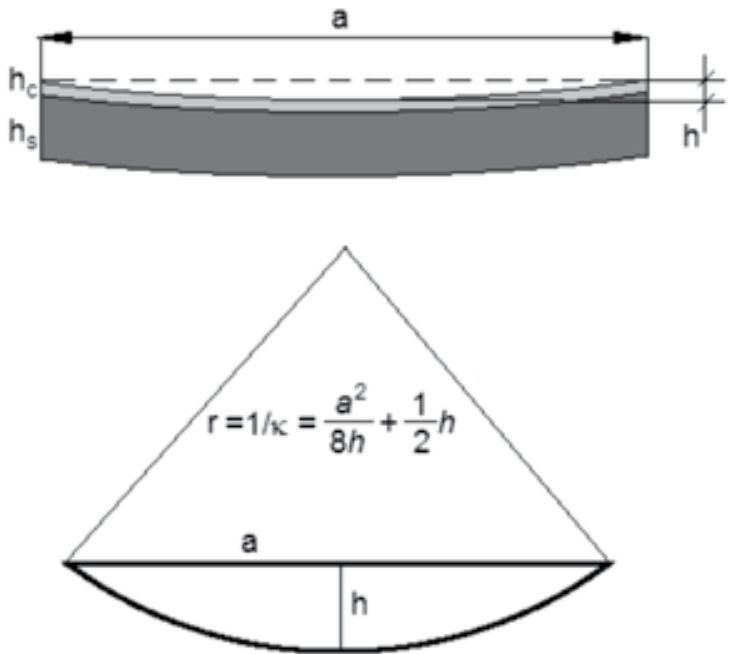

Rys. 4. Schemat obliczania promienia i krzywizny wygięcia na podstawie ugięcia próbki

Fig. 4. The scheme of calculation the sample radius and curvature after coating deposition

i wymiary natryskiwanych wcześniej próbek. Na model nałożono siatkę elementów skończonych składającą się z 5.700 ośmiowęzłowych (łącznie 17.739 węzłów) elementów czworokątnych (rys. 5). Dane materiałowe dla ceramiki $\mathrm{Al}_{2} \mathrm{O}_{3}$ i miedzi, niklu oraz tytanu przyjęto na podstawie dostępnych źródeł literaturowych

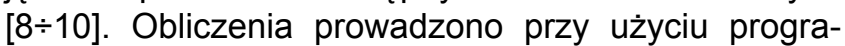
mu LUSAS v.14-7 opartego na metodzie elementów skończonych. Zagadnienie rozwiązywano jako dwuwymiarowe w płaskim stanie naprężenia w zakresie termosprężystym. Zbudowano po 3 modele z powłoką miedzianą, tytanową i niklową o grubościach powłok wynoszących odpowiednio: 0,105; 0,110 i 0,133 mm i stałej grubości podłoża $\mathrm{Al}_{2} \mathrm{O}_{3}$ równej $0,593 \mathrm{~mm}$.

Model ten obciążano różnicą temperatury (spadkiem) o takiej wielkości, aby wywołać wygięcie próbki wynikające ze zróżnicowanego skurczu poprzecznego materiału powłoki oraz podłoża. Dla każdego materiału powłoki oraz jej grubości zmieniano wielkość obciążenia termicznego (spadku temperatury) połączenia w ten sposób, aby uzyskać ugięcia zbliżone do zmierzonych na rzeczywistych próbkach. Umożliwiło to określenie wielkości oraz rozkładu naprężeń własnych w badanych układach powłoka-podłoże. 
Ponieważ próbki z natryskanymi na podłoże $\mathrm{Al}_{2} \mathrm{O}_{3}$ powłokami $\mathrm{Cu}, \mathrm{Ti}, \mathrm{Ni}$ ulegały różnym wygięciom to wielkość obciążenia termicznego modelu była różna dla poszczególnych materiałów. Uzyskano zgodność wygięcia modelu MES z wygięciem próbek mierzonym po natrysku HVOF dla następujących wielkości obciążenia: dla powłoki Cu było to $\Delta \mathrm{T}=100^{\circ} \mathrm{C}$, dla powłoki $\mathrm{Ni}-\Delta \mathrm{T}=95^{\circ} \mathrm{C}$, dla powłoki $\mathrm{Ti}-\Delta \mathrm{T}=425^{\circ} \mathrm{C}$.

Dla celów porównawczych otrzymanych wyników analizowano jedynie składową naprężenia $\sigma_{x x}$ na kierunku $x$. Na rysunku 6 przedstawiono mapę obrazującą rozkład naprężeń $\sigma_{x x}$ obliczony dla modelu z powłoką miedzianą $\left(\Delta T=100^{\circ} \mathrm{C}\right)$. W pozostałych analizowanych modelach (powłoki $\mathrm{Ni}$ i Ti) rozkłady naprężeń $\sigma_{x x}$ były jakościowo identyczne z modelem z powłoką miedzianą.

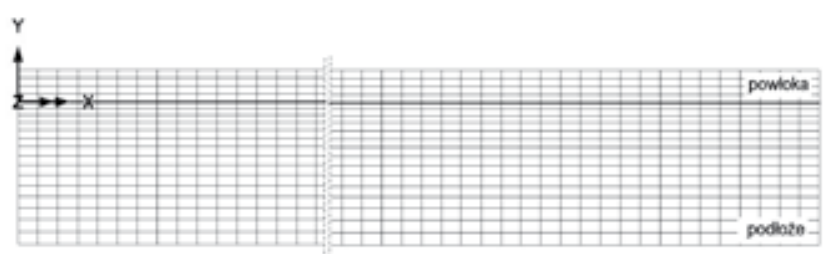

Rys. 5. Siatka elementów skończonych dla modelu powłoki nałożonej na podłoże ceramiczne

Fig. 5. The finite element mesh of the model of coating deposited onto ceramic substrate

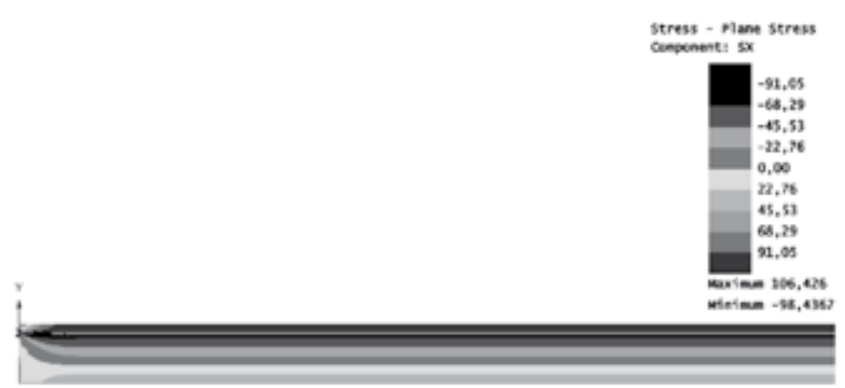

Rys. 6. Mapa (fragment) rozkładu naprężenia $\sigma_{x x}$ w modelu powłoki $\mathrm{Cu}$ na podłożu $\mathrm{Al}_{2} \mathrm{O}_{3}$ chłodzonych do temperatury otoczenia $\left(\Delta \mathrm{T}=100^{\circ} \mathrm{C}\right)$ Fig. 6. The map (a part) of $\sigma_{x x}$ stress distribution in the model of $\mathrm{Cu}$ coating on $\mathrm{Al}_{2} \mathrm{O}_{3}$ substrate cooled down to ambient temperature $\left(\Delta \mathrm{T}=100^{\circ} \mathrm{C}\right)$

\section{Wyniki obliczeń naprężeń}

Końcowe naprężenia własne $\left(\sigma_{\text {res }}\right)$ w natryskiwanych powłokach są sumą naprężeń pochodzących od chłodzenia natryskiwanych cząstek materiału na podłożu $\left(\sigma_{q}\right)$ oraz naprężeń powstających w czasie chłodzenia utworzonej powłoki i podłoża jako całości $\left(\sigma_{c}\right)$ :

$$
\sigma_{\text {res }}=\sigma_{q}+\sigma_{c}
$$

Wyznaczone rozkłady naprężeń w powłoce i podłożu $\left(\sigma_{\text {res }}\right)$ z wykorzystaniem pomiarów krzywizny wygięcia próbek zawierają w sobie oba rodzaje naprężeń wynikających z całego procesu formowania się powłoki metalowej na ceramicznym podłożu. Przeprowadzone modelowanie numeryczne naprężeń własnych obejmowało naprężenia pochodzące od fazy chłodzenia utworzonej na podłożu ceramicznym powłoki metalowej $\left(\sigma_{c}\right)$. Stąd, odejmując od naprężeń wyznaczonych na podstawie krzywizny wygięcia próbek naprężenia obliczone metodą MES otrzymamy tę część naprężeń własnych $\left(\sigma_{c}\right)$, jaka wynika z procesu formowania się powłoki metalowej aż do osiągnięcia pełnej grubości.

Na rysunkach $7 \div 9$ przedstawiono rozkłady naprężeń własnych $\mathrm{w}$ analizowanych powłokach miedzianych, niklowych oraz tytanowych wyznaczone w oparciu o model Clyne'a na podstawie pomiarów krzywizny wygięcia próbek, tzn. naprężenia sumaryczne $\left(\sigma_{\text {res }}\right)$, naprężenia obliczone numerycznie dla etapu chłodzenia utworzonego układu powłoka-podłoże do temperatury otoczenia $\left(\sigma_{c}\right)$, oraz naprężenia od natrysku - opisujące etap osadzania się powłoki metalowej na podłożu ceramicznym $\left(\sigma_{q}\right)$ wyznaczone geometrycznie przez odjęcie rozkładów naprężeń $\sigma_{c}$ od naprężeń $\sigma_{\text {res }}$.

$Z$ przedstawionych obliczeń wynika, że naprężenia końcowe $\left(\sigma_{\text {res }}\right)$ we wszystkich natryskiwanych powłokach mają charakter rozciągający o wartościach do $130 \mathrm{MPa}$ dla miedzi, $333 \mathrm{MPa}$ dla niklu oraz do $92 \mathrm{MPa}$ dla tytanu. Na granicy powłoka-podłoże występuje skok naprężenia do wartości ujemnych (powłoka $\mathrm{Cu}, \mathrm{Ti}$ ) lub dodatnich (powłoka Ni) po stronie ceramiki. Niska różnica współczynników rozszerzalności cieplnych między tytanem i ceramiką sprzyja niezbyt wysokiemu poziomowi naprężeń w powłoce. Podobne wielkości naprężeń wyznaczono w powłoce miedzianej, dla której ta różnica jest stosunkowo wysoka. Jednak z pewnością ma tu bardzo duży wpływ wysoka plastyczność miedzi, dzięki której łatwość deformacji plastycznej umożliwia znaczną redystrybucję naprężeń podczas tworzenia i stygnięcia układu powłoka-podłoże. W tym kontekście, w powłoce niklowej wyznaczone naprężenia są dużo wyższe niż w pozostałych powłokach. $Z$ jednej strony nikiel ma niewiele niższy współczynnik rozszerzalności cieplnej od miedzi, ale z drugiej nie jest na tyle plastyczny, aby w takim stopniu jak miedź redukował poziom naprężeń.

Wielkość naprężeń w powłoce zależy w dużym stopniu od właściwości cieplnych oraz fizycznych materiału powłoki i podłoża. Dominującą rolę odgrywa tu różnica współczynników rozszerzalności cieplnych obu materiałów czy też różnica ich sztywności opisana przez moduł Younga. Obie te wielkości są często zależne od temperatury, przy czym współczynnik rozszerzalności cieplnej $(\alpha)$ większości metali i ceramiki rośnie z temperaturą, a moduł Younga $(E)$ maleje.

Z pewnym przybliżeniem można założyć, że iloczyn $\alpha \bullet E$ dla danego materiału jest wartością niezmienną od temperatury. Taka zależność wykorzystywana jest przez wielu autorów do oceny równoczesnego wpływu tych dwóch właściwości na wielkość naprężeń w konstrukcji. W przypadku analizowanych materiałów powłokowych zależność tę przedstawiono na rysunku 10. Na jej podstawie widać, że powyżej pewnej wielkości iloczynu $\alpha \cdot E(2,2 \div 2,5)$ następuje gwałtowny wzrost naprężeń w powłoce oraz skok naprężenia na granicy połączenia. 


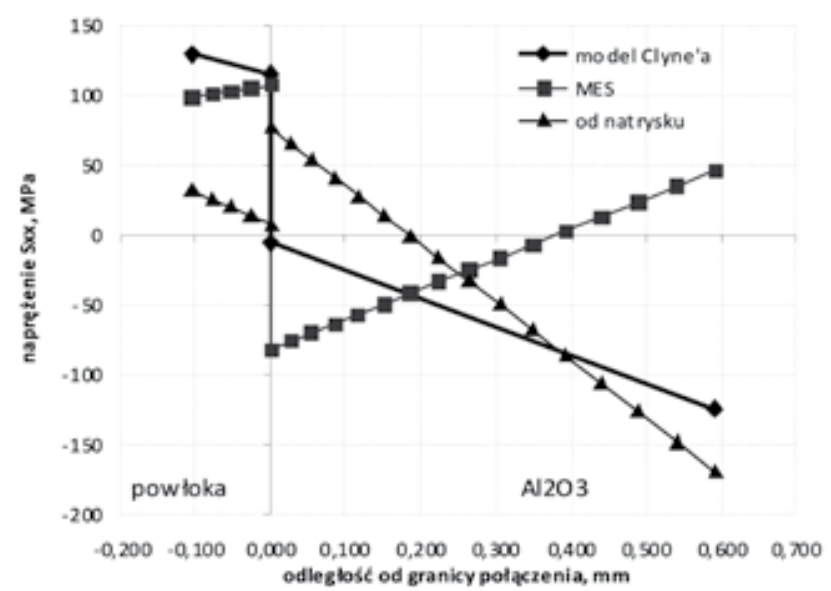

Rys. 7. Rozkład naprężeń własnych $\sigma_{x x}$ w powłoce miedzianej natryskiwanej na podłoże $\mathrm{Al}_{2} \mathrm{O}_{3}$

Fig. 7. Residual stress distribution $\left(\sigma_{x x}\right)$ in Cu coating thermally sprayed on $\mathrm{Al}_{2} \mathrm{O}_{3}$ substrate

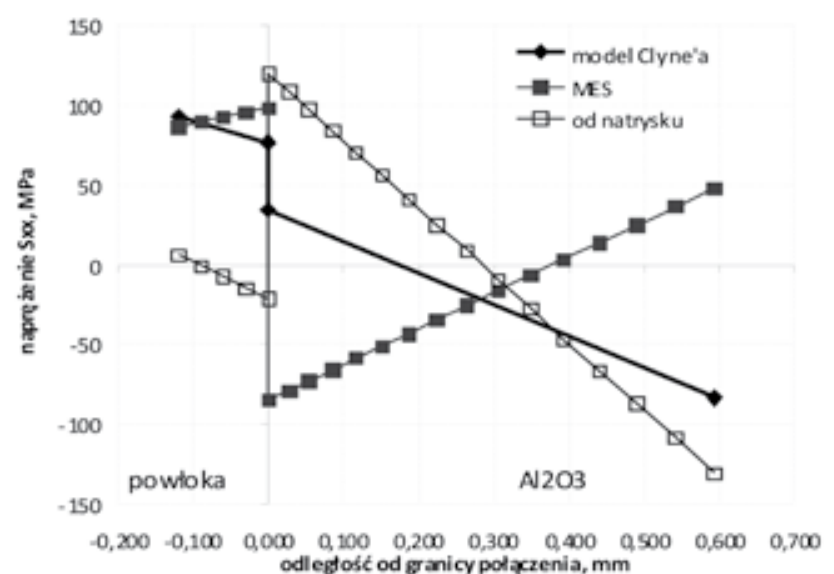

Rys. 9. Rozkład naprężeń $\sigma_{x x}$ w powłoce tytanowej natryskiwanej na podłożu $\mathrm{Al}_{2} \mathrm{O}_{3}$

Fig. 9. Residual stress distribution $\left(\sigma_{x x}\right)$ in Ti coating thermally sprayed on $\mathrm{Al}_{2} \mathrm{O}_{3}$ substrate

\section{Wnioski}

Przedstawiono sposób wyznaczania naprężeń własnych na przykładzie powłok metalowych $(\mathrm{Cu}$, $\mathrm{Ni}, \mathrm{Ti})$ natryskiwanych na podłoże ceramiczne $\mathrm{Al}_{2} \mathrm{O}_{3}$ metodą HVOF. Wykorzystano w tym celu równania (Clyne'a) oparte na modelu dwóch płyt, w których występuje niedopasowanie odkształceń $\Delta \varepsilon$. Stanowią one rozwinięcie modelu Stoneya, opracowanego dla warunków, gdy powłoka jest dużo cieńsza od podłoża, co w przypadku procesów natryskiwania najczęściej nie występuje. Obliczenia naprężeń opierają się na zmierzonym po procesie natryskiwania ugięciu próbki i wyznaczonym na tej podstawie promieniu oraz krzywiźnie wygięcia. Obliczone na tej podstawie wielkości obrazują naprężenia własne końcowe w układzie powłoka-podłoże po całym procesie natryskiwania. Badania uzupełniono o oblicze-

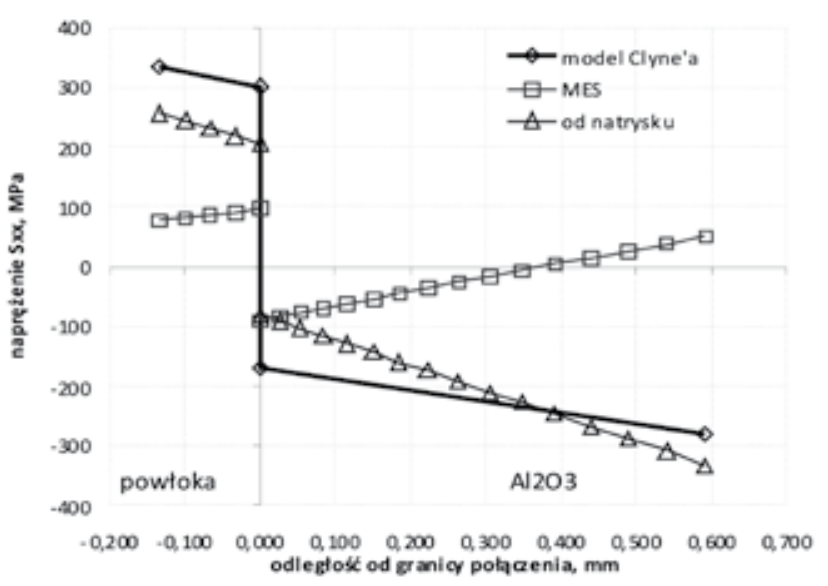

Rys. 8. Rozkład naprężeń $\sigma_{x x}$ w powłoce niklowej natryskiwanej na podłożu $\mathrm{Al}_{2} \mathrm{O}_{3}$

Fig. 8. Residual stress distribution $\left(\sigma_{x x}\right)$ in Ni coating thermally sprayed on $\mathrm{Al}_{2} \mathrm{O}_{3}$ substrate

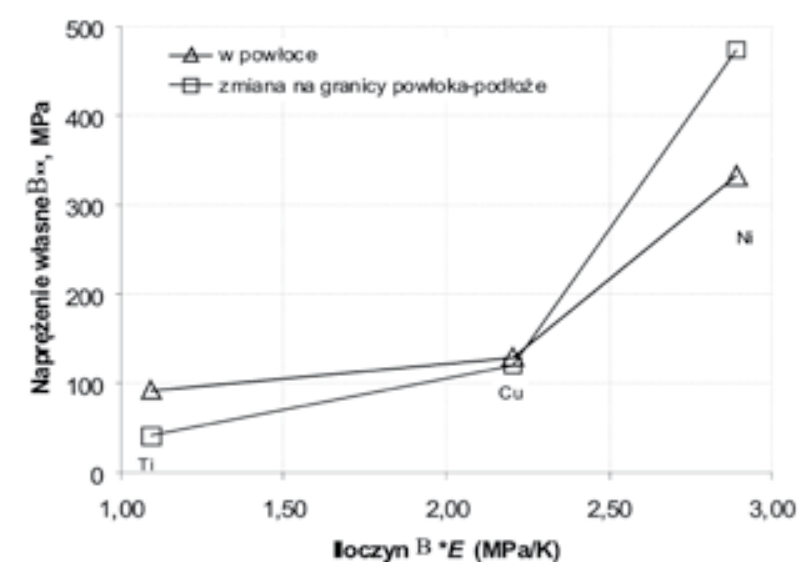

Rys. 10. Wpływ iloczynu współczynnika rozszerzalności cieplnej i modułu Younga powłoki na wielkość naprężeń w powłoce oraz różnicę naprężeń na granicy powłoka-podłoże

Fig. 10. The relation between the product $\alpha \cdot E$ for the coating and the residual stresses in coating and stress change at the coatingsubstrate interface.

nia numeryczne (MES) dla modeli odzwierciedlających badane materiały, w których wprowadzono takie obciążenie termiczne, aby uzyskać zbliżone ze zmierzonymi wygięcia próbek. Otrzymane naprężenia stanowią część naprężeń końcowych obrazującą stan wynikający $z$ etapu chłodzenia utworzonej na podłożu ceramicznym powłoki metalowej. Pozostałą część naprężeń obejmuje stan z etapu formowania się powłoki na podłożu w procesie nanoszenia materiału powłokowego. Została ona w pracy wyznaczona na podstawie różnicy naprężeń całkowitych oraz naprężeń wyznaczonych $z$ etapu chłodzenia utworzonej na podłożu ceramicznym powłoki. Należy podkreślić, że obliczenia zawierają wiele uproszczeń, przez co rzeczywisty stan naprężeń w badanych układach może różnić się od podanego. 
Wpływają na to liczne czynniki, jak np. zagadnienia związane z deformacją plastyczną cząstek metalu padających na podłoże i ich dalszym płynięciem plastycznym, czy też zagadnienia niestacjonarnego przepływu i wymiany ciepła między powierzchniami powłoki i podłoża.

Analizie naprężeń poddano trzy materiały powłokowe różniące się właściwościami cieplno-fizycznymi i mechanicznymi. Z punktu widzenia ich połączenia z podłożem ceramicznym $\mathrm{Al}_{2} \mathrm{O}_{3}$ zarówno miedź, jak i nikiel mają od niej znacznie wyższe współczynniki rozszerzalności cieplnej, podczas gdy dla tytanu ta różnica jest nieznaczna. $Z$ drugiej strony wysoka plastyczność miedzi sprzyja jej deformacji i powstawaniu odkształceń plastycznych, które w dużym stopniu ułatwiają redystrybucję powstających naprężeń co trudniej osiągąć w materiałach o wyższej granicy plastyczności (Ni, Ti). Przedstawione w pracy wspólne oddziaływanie współczynnika rozszerzalności cieplnej $(\alpha)$ oraz sztywności powłoki opisanej modułem Younga (E) na naprężenia w powłoce i na granicy powłoka-podłoże pokazało, że przekrocze- nie pewnej wartości iloczynu $\alpha \cdot E(2,2 \div 2,5)$ prowadzi do szybkiego wzrostu naprężeń rozciągających w powłoce, co wystąpiło w przypadku powłoki niklowej charakteryzującej się wysokim współczynnikiem $\alpha$ oraz większą sztywnością w stosunku do pozostałych materiałów. Dalsze badania z udziałem większej liczby materiałów powłokowych o zróżnicowanych właściwościach są wskazane, aby potwierdzić opisane zależności.

Przedstawiona analiza zakłada czysto sprężyste zachowanie się materiałów, co w rzeczywistości spełnione jest jedynie dla ceramicznego podłoża. Niemniej jednak powstające po procesie natryskiwania wygięcia próbek są na tyle małe, że mieszczą się w zakresie sprężystym, dla którego ważne są zależności opracowane dla modelu dwóch płyt. Uzyskane wyniki odzwierciedlają więc w pewnym stopniu proces powstawania naprężeń własnych w natryskiwanych powłokach metalowych i z tego względu są ważnym elementem charakterystyki właściwości natryskiwanych powłok. Zaletą przestawionej metody oceny naprężeń jest łatwość i niski koszt jej przeprowadzenia.

\section{Literatura}

[1] Pawłowski L.: The Science and Engineering of Thermal Spray Coatings. John Wiley \& Sons, Ltd. 2008.

[2] Lindemann Z., Zimmerman J., Golański D., Chmielewski T. Włosiński W.: Modelowanie naprężeń własnych generowanych w procesie termicznego nanoszenia powłok. Biuletyn Instytutu Spawalnictwa, Nr 5/2012, s. 128-133.

[3] Ju D.Y., Nishida M., Hanabusa T.: Simulation of the thermomechanical behavior and residual stresses in the spray coating process. Journal of Materials Processing Technology 92-93 (1999) 243-250.

[4] Totemeier T.C., Wright J.K.: Residual stress determination in thermally sprayed coatings - a comparison of curvature models and X-ray techniques. Surface \& Coatings Technology 200 (2006) 3955 - 3962

[5] Clyne T.W., Gill S.C.: Residual Stresses in Surface Coatings and Their Effects on Interfacial Debonding: A Review of Recent Work. J. Thermal Spray Technology 5(4) (1996) 401-418.
[6] Stoney G.G.: The Tension of Metallic Films deposited by Electrolysis. Proc. R. Soc. London, A82 (1909) 172-175.

[7] Tsui Y.C., Clyne T.W.: An analytical model for predicting residual stresses in progressively deposited coatings Part 1: Planar geometry. Thin Solid Films vol. 306 (1997) 23-33.

[8] Goldsmith A., Waterman T.E., Hirchorn H.J.: Handbook of thermophysical properties of solid materials. New York 1961.

[9] Boyer R., G. Welsch, E. Collings ed.: Materials Property Handbook. Titanium Alloys ASM International, Materials Park, OH, 1994.

[10] Handbook of Engineering Tables ed. R.C. Dorf, CRC Press LLC, 2004.

\section{Podziękowanie}

Dziękujemy firmie Resurs sp. z.o.o. oraz Panu Andrzejowi Radziejewskiemu za udostępnienie urządzenia do natrysku metodą HVOF. Praca finansowana z projektu Narodowego Centrum Nauki nr N N519 652840. 